\title{
Sublumbar Lymph Node
}

National Cancer Institute

\section{Source}

National Cancer Institute. Sublumbar Lymph Node. NCI Thesaurus. Code C77655.

A lymph node located under the spine. 